\title{
KOMPOSISI SENYAWA BIOAKTIF DAN UJI AKTIVITAS ANTIBAKTERI MINYAK ATSIRI DAUN KAYU PUTIH (Melaleuca cajuputi) DARI KOTA SINGKAWANG
}

\author{
(Bioactive Composition and Antibacterial Activities Test of Cajuput Leaf Essential Oil (Melaleuca \\ cajuputi) from the City of Singkawang)
}

\author{
Muhamad Agus Wibowo, Devi Novita Sari, Afghani Jayuska, \\ Puji Ardiningsih \\ Program Studi Kimia, Fakultas MIPA, Universitas Tanjungpura, \\ Jl. Prof. Dr. H. Hadari Nawawi, Pontianak \\ e-mail: m.agus.wibowo@chemistry.untan.ac.id
}

Diterima 16 Desember 2020, Revisi akhir 05 April 2021, Disetujui 26 Mei 2021

\begin{abstract}
ABSTRAK. Kayu putih (Melaleuca cajuputi) merupakan tumbuhan yang banyak dijumpai di pesisir pantai Kota Singkawang. Tumbuhan ini berpotensi digunakan untuk mengobati diare. Penelitian ini bertujuan untuk mengetahui aktivitas antibakteri daun kayu putih yang berasal dari Kota Singkawang terhadap bakteri uji Escherichia coli dan Staphylococcus aureus. Metode yang digunakan untuk isolasi minyak atsiri yaitu distilasi uap, sedangkan uji aktivitas antibakteri menggunakan metode difusi sumuran. Hasil isolasi minyak atsiri daun kayu putih menghasilkan rendemen sebesar 0,55\%. Analisis GC-MS menghasilkan 26 puncak senyawa dengan 2 senyawa utama yaitu 1,8 sineol sebesar 71,96\% dan alpha-terpineol sebesar $11,44 \%$. Hasil uji aktivitas antibakteri minyak atsiri daun kayu putih terhadap bakteri E. coli dan S. aureus menghasilkan aktivitas yang tergolong lemah. Diameter zona hambat terhadap bakteri E. coli dengan konsentrasi $50 \mu \mathrm{g} / \mu \mathrm{l}$ menghasilkan zona sebesar 4,39 mm, sedangkan pada bakteri S. aureus yaitu sebesar $4,62 \mathrm{~mm}$.
\end{abstract}

Kata kunci: Escherichia coli, Melaleuca cajuputi, minyak atsiri daun kayu putih, Singkawang, Staphylococcus aureus

\begin{abstract}
Eucalyptus (Melaleuca cajuputi), is a plant which often found on the coast of the city of Singkawang, West Kalimantan. This plant is potentially used to treat diarrhea. This study aimed to determine antibacterial activity of eucalyptus leaf from Singkawang city on bacteria Escherichia coli and Staphylococcus aureus. Isolation of the essential oils was using steam distillation, while the analysis of antibacterial activity with well diffusion method. The isolation resulted $0.55 \%$ yield. Analysis using GCMS yielded 26 peak compounds with 2 main compounds namely 1.8 cineol at $71.96 \%$ and alpha-terpineol $11.44 \%$. Furthermore, antibacterial activity test of eucalyptus leaf essential oil against E. coli and S. aureus bacteria belongs to the category of low. The diameter of the inhibition zone on bacteria E. coli at a concentration of $50 \mu \mathrm{g} / \mu \mathrm{l}$ obtained $4.39 \mathrm{~mm}$ zone, while on S. aureus was $4.62 \mathrm{~mm}$ zone.
\end{abstract}

Keywords: Eucalyptus leaf essential oil, Eschericia coli, Melaleuca cajuputi, Singkawang,

Stapylococcus aureus

\section{PENDAHULUAN}

Tumbuhan kayu putih spesies Melaleuca (Myrtaceae) adalah tanaman asli Australia Utara dan Australia Tenggara (Susanto et al., 2003). Tumbuhan ini telah dimanfaatkan secara turuntemurun sebagai tanaman obat (Hai et al., 2019).
Daunnya diekstrak secara tradisional oleh masyarakat maupun secara komersial menjadi produk minyak atsiri kayu putih (Maulidah, 2010). Indonesia memiliki pabrik minyak kayu putih terbesar di dunia dikelola oleh PT. Sanggaragro Karya Persada yang berada di Nusa Tenggara Barat. Tumbuhan kayu putih menyebar di Indonesia, 
terutama di Kepulauan Jawa, Maluku, Papua, dan Nusa Tenggara Barat (Maulidah, 2010; Susanto et al., 2003).

Singkawang merupakan salah satu daerah di Kalimantan Barat yang cukup banyak ditumbuhi tumbuhan kayu putih. Berdasarkan informasi yang didapat dari masyarakat sekitar, tumbuhan ini tumbuh secara alami dan belum dimanfaaatkan secara produktif. Penelitian Helfiansah et al. (2013) menyatakan minyak kayu putih merupakan salah satu minyak atsiri yang banyak digunakan sebagai bahan medis atau produk farmasi. Kebutuhan minyak ini meningkat $10 \%$ setiap tahunnya (Rusli, 2010). Penggunaan minyak kayu putih diminati baik usia anak-anak maupun orang dewasa. Indikasi sakit perut, mual, sakit kepala, hingga gatal-gatal akibat gigitan serangga menjadi pilihan penggunaan minyak ini.

Senyawa utama penyusun minyak atsiri daun kayu putih yaitu senyawa 1,8 sineol dan alpha terpineol (Padalia et al., 2015; Sutrisno dan Retnosari, 2018). Penelitian Padalia (2015) menyatakan kandungan utama senyawa minyak atsiri daun kayu putih yaitu senyawa 1,8 sineol sebesar $77,40 \%$ dan a-terpineol sebesar $7,72 \%$. Beberapa penelitian juga melaporkan mengenai bioaktivitas dari minyak atsiri daun kayu putih. Penelitian Nazeh et al. (2015) menyatakan ekstrak bunga dan daun kayu putih memiliki aktivitas antioksidan dan antibakteri terhadap bakteri Bacillus cereus, S. aureus dan Staphylococcus epidermis. Penelitian Cuong dan Xuyen (1994) melaporkan bahwa minyak atsiri daun kayu putih memiliki aktivitas antibakteri terhadap bakteri $S$. aureus, E. coli dan Pseudomonas aeruginosa. Bakteri E. coli dan S. aureus merupakan bakteri patogen yang dilaporkan resisten terhadap antibiotik (Nasronudin, 2011).

E. coli merupakan bakteri gram negatif yang sebagian besar tidak berbahaya, namun beberapa jenis bakteri ini bersifat patogen. Infeksi pada manusia menyebabkan diare encer, diare berdarah, dan sindrom homolitik uremik yaitu kondisi kerusakan sel darah merah dan penurunan trombosit (Ghyles, 2007). S. aureus merupakan bakteri gram positif yang dapat menyebabkan mulai dari infeksi kulit ringan, keracunan makanan hingga menyebabkan infeksi berat pneumonia, infeksi saluran kemih, dan endokarditis (Rahmi et al., 2015; Warsa, 1994).

Berdasarkan kajian pustaka di atas maka penelitian ini bertujuan untuk menentukan kandungan senyawa bioaktiv pada minyak atsiri daun kayu putih (Melaleuca cajuputi) dari Kota
Singkawang serta menentukan aktivitas hambatnya terhadap bakteri $S$. aureus dan E. coli.

\section{METODE PENELITIAN}

Bahan utama yang digunakan pada penelitian ini adalah tumbuhan kayu putih yang diperoleh dari daerah Singkawang yaitu di Jl. Pasir Panjang Desa Sadau, Kecamatan Singkawang Selatan, Kota Singkawang, Kalimantan Barat. Titik koordinat lokasi pengambilan yaitu 0'50'26'N 108'53'02'E. Alat-alat yang digunakan yaitu autoclave (All American), hotplate (Torrey Pines), inkubator (Binder), jangka sorong (Krisbow Vernier), Laminar air flow (SZ Air Tech), piknometer (Pyrex), seperangkat alat destilasi, GCMS QP2010 (Shimadzu), oven (Binder) dan alat laboratorium lainnya. Sementara itu, bahan yang digunakan yaitu akuades (H2O), etanol (Merck), antibiotik amoksilin (Kimia Farma), etil asetat (Merck), Nutrient Agar (Himedia), Nutrient broth (Himedia), natrium sulfat anhidrat (Merck) dan bahan analitik lainnya.

\section{Preparasi Sampel}

Tumbuhan kayu putih bagian akar, ranting, bunga, buah, dan daun di determinasi. Daun kayu putih yang akan diisolasi dikeringkan selama \pm 24 jam tanpa terkena matahari secara langsung. Selanjutnya daun kayu putih dipotong kira-kira berukuran $1-4 \mathrm{~cm}$ dan ditimbang sebanyak $2,32 \mathrm{~kg}$ berat kering.

\section{Isolasi Minyak Atsiri Daun Kayu Putih}

Daun kayu putih diisolasi menggunakan distilasi uap dengan mengacu pada metode Mayasari et al. (2013) yang dimodifikasi. Sampel dimasukkan ke dalam alat destilator kemudian dialiri uap dengan tekanan uap dijaga konstan. Waktu penyulingan minyak kayu putih dilakukan selama 4 jam. Destilat yang dihasilkan berupa dua lapisan yaitu air dan minyak, kemudian dipisahkan dengan corong pisah. Minyak yang diperoleh ditambah dengan natrium sulfat anhidrat. Selanjutnya minyak dipisahkan dari natrium sulfat anhidrat. Hasil minyak atsiri dihitung rendemen dan diidentifikasi komponen kimianya menggunakan alat GC-MS. Berikut rumus yang digunakan untuk memperoleh rendemen:

$$
\text { Rendemen }=\frac{\text { massa minyak }(g)}{\text { massa } \operatorname{sampel}(g)} \times 100 \%
$$


Analisis Minyak Atsiri dengan Gas Chromatography - Mass Spectrometry

Analisis kandungan senyawa pada minyak kayu putih dilakukan dengan menggunakan alat Gas Chromatography-Mass Spectrometry (GC-MS) QP2010 (Shimadzu, Japan) dengan mengacu metoda Painuli et al. (2016) yang dimodifikasi. Analisis dilakukan dengan menggunakan kolom Rtx 5 MS panjang $30 \mathrm{~m}$ dengan gas pembawa helium dan pengion EI 70 Ev. Adapun kondisi alat diatur dengan suhu oven kolom $50{ }^{\circ} \mathrm{C}$, Temperatur Injeksi $300{ }^{\circ} \mathrm{C}$, tekanan $13 \mathrm{kPa}$, Total aliran 79,3 $\mathrm{mL} / \mathrm{min}$ dan aliran kolom $0,55 \mathrm{~mL} / \mathrm{min}$.

\section{Penentuan Bobot Jenis}

Penentuan bobot jenis dilakukan mengacu pada SNI 3954-2014 dengan menggunakan alat piknometer. Piknometer berukuran $5 \mathrm{ml}$ dicuci dan dibersihkan, kemudian dibilas menggunakan dietil eter. Piknometer ditimbang kosong, lalu piknometer dikeluarkan dari timbangan dan diisi dengan akuades hingga penuh dihindari adanya gelembung udara. Piknometer yang sama dibersihkan dan dikeringkan. Piknometer diisi dengan minyak atsiri, kemudian ditimbang. Hasil yang diperoleh dihitung dengan rumus:

Keterangan:

$$
\text { Bobot jenis }=\frac{b-a}{c-a}
$$

$\mathrm{a}=$ berat pinometer kosong

$\mathrm{b}=$ berat pikno+minyak atsiri

$\mathrm{c}=$ berat pikno+air

\section{Peremajaan Bakteri Uji E. coli dan S. aureus}

Peremajaan bakteri uji dilakukan dengan menggunakan metode Wijayati et al. (2014). Stok bakteri uji ditanam dengan mengambil 1 ose bakteri uji dan digoreskan di media NA diinkubasi pada suhu $37{ }^{\circ} \mathrm{C}$ selama 24 jam.

\section{Pembuatan Kultur Bakteri uji}

Pembuatan kultur bakteri uji menggunakan metode Wijayati et al. (2014). Kultur bakteri uji ditanamkan dengan mengambil 1 ose koloni bakteri pada media NB dan diinkubasi pada suhu $37{ }^{\circ} \mathrm{C}$ selama 24 jam.

\section{Uji Aktivitas Antibakteri}

Uji aktivitas antibakteri dilakukan dengan metode Wijayati et al. (2014). Penentuan uji aktivitas antibakteri menggunakan metode difusi sumuran. Sebanyak $60 \mu \mathrm{l}$ kultur bakteri diambil dan dicampur dengan media NA sebanyak $\pm 20 \mathrm{ml}$, selanjutnya dituang kedalam petri. Media dibiarkan memadat, kemudian dibuat 4 sumur pada media. Sebanyak $20 \mu \mathrm{l}$ minyak atsiri daun kayu putih dengan konsentrasi $50 \mu \mathrm{g} / \mu \mathrm{l}, 25 \mu \mathrm{g} / \mu \mathrm{l}$, beserta kontrol positif dan negatif dimasukkan kedalam sumur. Kontrol positif yang digunakan yaitu antibiotik amoksilin $1 \mu \mathrm{g} / \mu \mathrm{l}$ sementara kontrol negatif menggunakan etil asetat. Sampel yang akan diuji diinkubasi selama 24 jam pada suhu $37^{\circ} \mathrm{C}$. Zona bening diukur menggunakan jangka sorong.

\section{Uji bakteriostatik dan bakteriosidal}

Uji aktivitas bakteriostatik dan bakteriosidal dilakukan dengan merujuk metode Pankey and Sabath (2004). Uji dilakukan untuk menentukan jenis karakteristik bakteri baik bersifat bakteriostatik atau bakteriosidal, dengan cara mengambil 1 ose dari isolat zona bening yang dihasilkan. Isolat digoreskan di media NA dan diinkubasi selama 24 jam pada suhu $37{ }^{\circ} \mathrm{C}$.

\section{HASIL DAN PEMBAHASAN}

Isolasi daun kayu putih dari Kota Singkawang menggunakan metode distilasi uap menghasilkan rendemen minyak sebesar $0,55 \%$ dan bobot jenis sebesar 0,93 g. Hasil analisis menggunakan alat GC-MS menunjukkan 9 puncak senyawa (Tabel 1), dengan 2 senyawa utama yaitu 1,8 sineol dan alpha terpineol. Senyawa 1,8 sineol memiliki kelimpahan sebesar $71,96 \%$ dan senyawa alpha terpineol dengan kelimpahan 11,44\%. Berdasarkan data penelitian dari daerah Pulau Buru, Pulau Flores dan desa Pelita Jaya memiliki perbedaan komponen kimia yang dihasilkan dengan sampel minyak atsiri Kota Singkawang. Hasil menunjukkan bahwa lokasi pengambilan sampel cukup berpengaruh terhadap komponen kimia yang dihasilkan. Hasil ini didukung penelitian Astuti et al. (2014) lokasi pertumbuhan sampel berpengaruh besar terhadap komposisi kimia yang dihasilkan.

Berdasarkan data kadar sineol yang diperoleh sebesar $71,96 \%$ menghasilkan minyak dengan kualitas baik. Hal ini sesuai yang dilaporkan SNI 3954-2014 bahwa minyak atsiri daun kayu putih dengan kadar diatas $60 \%$ tergolong kualitas mutu super. Jika dibandingkan dengan beberapa sampel dari daerah Pulau Buru, Pulau Flores, dan desa Pelita Jaya, maka minyak kayu putih yang berasal dari Kota Singkawang memiliki kualitas lebih baik. Penelitian Mat dan Idroas (2019) juga menyatakan konstituen utama $M$. cajuputi yaitu 1,8 sineol, semakin tinggi kadar sineol pada minyak atsiri $M$. cajuputi maka kualitas minyak tersebut semakin baik. 
Tabel 1. Komponen kimia minyak atsiri daun kayu putih (Melaleuca cajuputi) beberapa daerah

\begin{tabular}{|c|c|c|c|c|c|}
\hline \multirow[b]{2}{*}{ No. } & \multirow[b]{2}{*}{ Senyawa Kimia } & \multicolumn{4}{|c|}{ Komponen Kimia (\%) } \\
\hline & & $\begin{array}{c}\text { Sampel } \\
\text { Singkawang, } \\
\text { Kalimantan Barat }\end{array}$ & $\begin{array}{l}\text { Pulau Buru, } \\
\text { Maluku (Sutrisno } \\
\text { and Retnosari, } \\
\text { 2018) }\end{array}$ & $\begin{array}{l}\text { Pulau Flores, } \\
\text { NTT (Sawu, } \\
\text { dkk. 2018) }\end{array}$ & $\begin{array}{c}\text { Pelita Jaya, } \\
\text { Maluku (Franz: } \\
\text { dkk. 2019) }\end{array}$ \\
\hline 1. & Alpa-pinene & $1,77 \%$ & $12,17 \%$ & - & $4,38 \%$ \\
\hline 2. & Beta-pinene & $1,66 \%$ & $1,08 \%$ & $0,47 \%$ & $2,48 \%$ \\
\hline 3. & Myrcene & $1,42 \%$ & - & $0,55 \%$ & - \\
\hline $4 .$. & 1,8 sineol & $71,96 \%$ & $50,64 \%$ & $62,6 \%$ & $63,17 \%$ \\
\hline 5. & Alpha-terpineol & $11,44 \%$ & $10,98 \%$ & $11,37 \%$ & - \\
\hline 6. & Beta.-Caryophyllene & $1,78 \%$ & $1,6 \%$ & - & - \\
\hline 7. & Alpha-humulene & $1,15 \%$ & $1,09 \%$ & $1,46 \%$ & $2,08 \%$ \\
\hline 8. & Aromaden drene & $1,21 \%$ & - & - & - \\
\hline 9. & Elemol & $1,62 \%$ & - & - & - \\
\hline
\end{tabular}

Keterangan (-): Tidak terdapat komponen kimia dalam minyak

Keberadaan senyawa1,8 sineol dibuktikan dari data spektra massa analisis MS yang menghasilkan puncak-puncak spektrum (Gambar 1). Data spektra massa dapat memberikan petunjuk untuk ion molekul, sehingga suatu pola fragmentasi dapat terbentuk. Senyawa 1,8 sineol dengan $\mathrm{m} / \mathrm{z}$ 154 mengalami fragmentasi membentuk beberapa fragmen (Gambar 2). Senyawa 1,8 sineol dengan kelimpahan $\mathrm{m} / \mathrm{z} \quad 154 \quad\left(\mathrm{C}_{10} \mathrm{H}_{18} \mathrm{O}\right)$ mengalami fragmentasi dengan melepaskan $\left(\mathrm{CH}_{3}\right)$ membentuk fragmen $\mathrm{m} / \mathrm{z} 139\left(\mathrm{C}_{9} \mathrm{H}_{15} \mathrm{O}\right)^{+}$. Senyawa dengan $\mathrm{m} / \mathrm{z}$ 139 melepaskan senyawa $\left(\mathrm{C}_{4} \mathrm{H}_{7}\right)$ membentuk fragmen $\mathrm{m} / \mathrm{z} 84\left(\mathrm{C}_{5} \mathrm{H}_{8} \mathrm{O}\right)^{+}$. Ion molekul $\mathrm{m} / \mathrm{z} 84$ kemudian mengalami fragmentasi melepaskan $\left(\mathrm{CH}_{3}\right)$ sehingga membentuk molekul dengan m/z 69 $\left(\mathrm{C}_{4} \mathrm{H}_{5} \mathrm{O}\right)$. Ion molekul dengan $\mathrm{m} / \mathrm{z} 154$ dapat membentuk fargmen yang berbeda dengan melepaskan senyawa $\left(\mathrm{C}_{7} \mathrm{H}_{12}\right)$ membentuk fragmen dengan $\mathrm{m} / \mathrm{z} 58\left(\mathrm{C}_{3} \mathrm{H}_{6} \mathrm{O}\right)$. Molekul dengan $\mathrm{m} / \mathrm{z} 58$ mengalami fragmen lagi membentuk ion molekul $\mathrm{m} / \mathrm{z} 43\left(\mathrm{C}_{2} \mathrm{H}_{3} \mathrm{O}\right)$, puncak ion molekul $\mathrm{m} / \mathrm{z} 43$ merupakan puncak tertinggi pada spektra massa senyawa 1,8 sineol dengan kelimpahan $100 \%$.
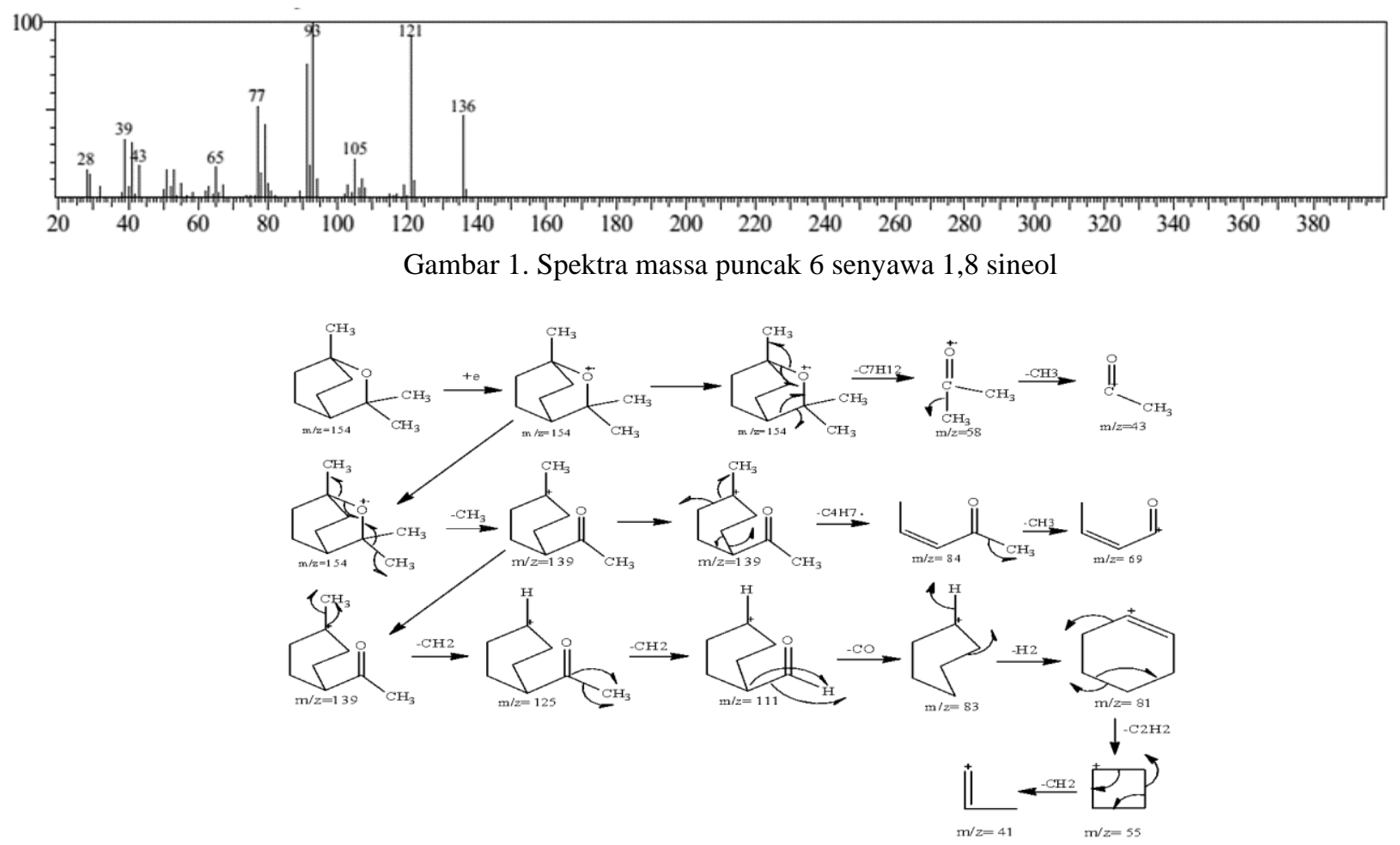

Gambar 2. Fragmentasi Senyawa 1,8 sineol 
Uji aktivitas minyak atsiri daun kayu putih dari Kota Singkawang menggunakan metode difusi sumuran dengan konsentrasi $50 \mu \mathrm{g} / \mu \mathrm{l}$ dan $25 \mu \mathrm{g} / \mu \mathrm{l}$. Hasil uji menunjukkan adanya aktivitas daya hambat terhadap bakteri $E$. coli dan $S$. aureus dengan ditandai munculnya zona bening disekitar sumuran (Gambar 3). Hasil uji terhadap bakteri $E$. coli dengan konsentrasi $50 \mu \mathrm{g} / \mu \mathrm{l}$ menghasilkan zona hambat sebesar $4,39 \mathrm{~mm}$, sementara dosis 25 $\mu \mathrm{g} / \mu \mathrm{l}$ menghasilkan zona hambat 3,44 $\mathrm{mm}$. Hal ini membuktikan semakin besar dosis yang digunakan dalam sampel, maka kemampuan sampel dalam menghambat juga semakin besar. Kemampuan daya hambat terhadap bakteri $S$. aureus menghasilkan zona hambat yang tidak berbeda jauh dari bakteri $E$. coli (Tabel 2). Jika dibandingkan dengan zona hambat amoksilin, kemampuan daya hambat terhadap E. coli dan S. aureus jauh lebih kecil, dalam hal ini amoksilin memiliki daya kerja lebih besar. Berdasarkan data (Tabel 2) menunjukkan hasil uji daya hambat tergolong lemah. Hasil ini didukung penelitian oleh Davis dan Stout (1971) yang menyatakan kekuatan daya hambat antimikroba dengan diameter zona hambat dapat dikelompokkan menjadi 4 yaitu, lemah (zona hambat $5 \mathrm{~mm}$ atau kurang); sedang (zona hambat 5$10 \mathrm{~mm}$ ); kuat (zona hambat 10-20 mm); dan sangat kuat (zona hambat $20 \mathrm{~mm}$ atau lebih).
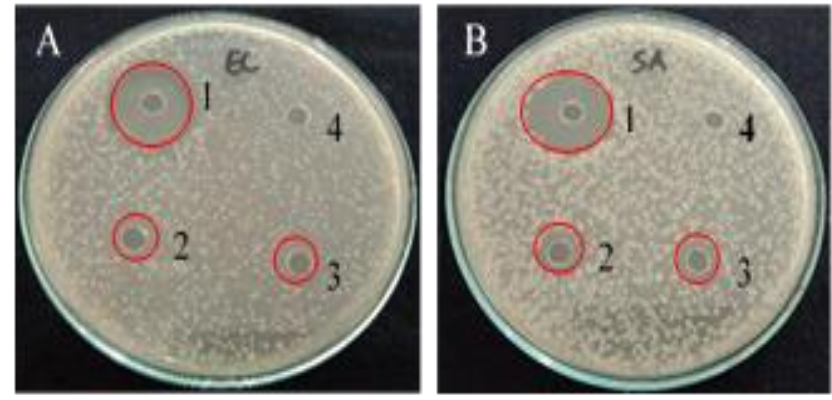

Gambar 3. Hasil zona bening minyak atsiri daun kayu putih terhadap bakteri A) E. coli dan B) S. aureus; 1) kontrol positif $(1 \mu \mathrm{g} / \mu \mathrm{l}$; 2) ekstrak minyak atsiri $(50 \mu \mathrm{g} / \mu \mathrm{l})$; 3) ekstrak minyak atsiri $(25 \mu \mathrm{g} / \mu \mathrm{l})$; 4) kontrol negatif

Tabel 2. Hasil Pengukuran Zona Hambat Jenis Bakteriostatik

\begin{tabular}{|c|c|c|c|c|}
\hline \multirow{2}{*}{ Sampel } & \multirow{2}{*}{ Dosis $\mu \mathrm{g} /$ well } & \multirow{2}{*}{ Konsentrasi } & \multicolumn{2}{|c|}{ Rata-rata Diameter Zona Hambat $(\mathrm{mm}) \pm$ STD } \\
\hline & & & E. coli & S. aureus \\
\hline & 1000 & $50 \mu \mathrm{g} / \mu \mathrm{l}$ & $4,39 \pm 0,48$ & $4,62 \pm 0,39$ \\
\hline Daun Kayu Putih & 500 & $25 \mu \mathrm{g} / \mu \mathrm{l}$ & $3,44 \pm 0,34$ & $3,08 \pm 0,33$ \\
\hline Amoksilin & 20 & $1 \mu \mathrm{g} / \mu \mathrm{l}$ & $18,14 \pm 0,24$ & $14,95 \pm 0,37$ \\
\hline
\end{tabular}

Keterangan: STD merupakan data standar deviasi dari 3 pengulangan

Hasil zona hambat yang diperoleh dilanjutkan uji karakteristik jenis bakteri. Berdasarkan hasil uji menunjukkan aktivitas antibakteri tergolong jenis bakteriostatik (Gambar 4). Bakteriostatik ditandai dengan munculnya koloni bakteri pada media uji. Hasil ini sesuai penelitian Kee dan Hayes (1993) yang menyatakan bahwa jenis bakteriostatik memiliki kemampuan menghambat bakteri dengan ditandai munculnya koloni bakteri pada media uji, sementara bakterisidal dapat membunuh bakteri ditandai dengan tidak munculnya koloni pada media uji. 


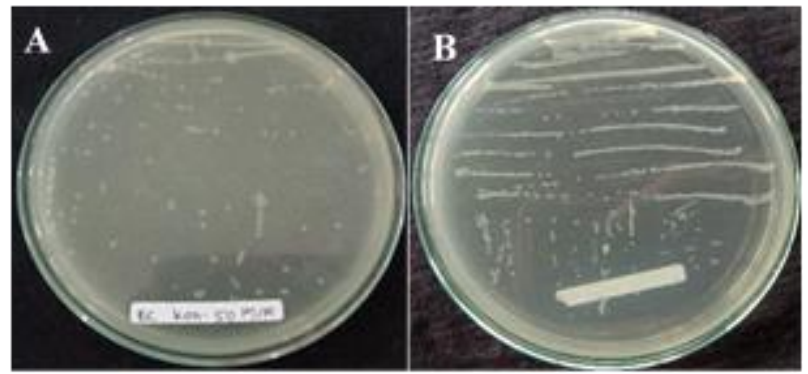

Gambar 4. Hasil uji bakteriostatik terhadap a) bakteri E. coli dan b) bakteri S. aureus

Ekstrak minyak atsiri daun kayu putih memiliki aktivitas antibakteri diduga pengaruh dari kandungan senyawa utama yaitu senyawa 1,8 sineol dan senyawa alpha-terpineol. Penelitian Li et al. (2009) menyatakan bahwa senyawa 1,8 sineol dan alpha terpineol memiliki potensi sebagai antibakteri terhadap bakteri $S$. aureus dan $E$. coli dengan mekanisme merusak membran sel. Penelitian Oyedemi et al. (2009) juga menyatakan mekanisme antibakteri dari komponen senyawa alpha terpineol yaitu disebabkan perubahan permeabilitas membran yang dapat menyebabkan lisis sel. Hal ini disampaikan oleh Pelczar dan Chan (2008) membran sel berperan penting dalam permeabilitas, transport nutrient ke dalam sel, dan pelepasan hasilhasil metabolisme ke luar sel. Kerusakan pada membran sel, maka fungsi permeabilitas membran juga akan mengalami kerusakan, sehingga menyebabkan sel menjadi terhambat dan mati.

\section{KESIMPULAN}

Hasil isolasi minyak atsiri daun kayu putih yang berasal dari daerah Singkawang menghasilkan rendemen sebesar $0,55 \%$. Analisis GC-MS menghasilkan 9 puncak senyawa dominan dengan 2 senyawa mayor yaitu senyawa 1,8 sineol dengan kelimpahan $71,96 \%$ dan alpha-terpineol $11,44 \%$. Hasil uji antibakteri minyak atsiri daun kayu putih menghasilkan aktivitas yang tergolong lemah. Diameter zona hambat terhadap bakteri E. coli dengan konsentrasi $50 \mu \mathrm{g} / \mu \mathrm{l}$ dan $25 \mu \mathrm{g} / \mu \mathrm{l}$ yaitu sebesar 4,39 $\mathrm{mm}$ dan 3,44 $\mathrm{mm}$. Hasil zona hambat terhadap bakteri $S$. aureus pada dosis yang sama yaitu sebesar 4,62 $\mathrm{mm}$ dan 3,08 $\mathrm{mm}$.

\section{DAFTAR PUSTAKA}

Astuti, E., Sunarminingsih, R., Jenie, U.A., Mubarika, S., \& Sismindari. (2014). Pengaruh lokasi tumbuh; umur tanaman dan variasi jenis destilasi terhadap komposisi senyawa minyak atsiri rimpang curcuma mangga produksi beberapa sentra di Yogyakarta. Jurnal Manusia dan Lingkungan, 21(3), 323-330.
Badan Standar Nasional. (2014). SNI 06-3954-2014, Minyak Kayu Putih. Jakarta: Badan Standar Nasional.

Cuong, N. D., \& Xuyen, T. T. (1994). Antibacterial properties of Vietnamese cajuput oil. J. of Essential Oil Research, 6(1), 63-67.

Davis, W.W., \& Stout, T.R. (1971). Disc plate method of microbiological antibiotic assay. American Society for Microbiology, 22(4), 659-665.

Franz, J. J., Maail, R. S., \& Titarsole, J. (2019). GC-MS Analisis terhadap kualitas minyak kayu putih asal Pelita Jaya Kabupaten Seram Bagian Barat Provinsi Maluku. Jurnal Hutan Pulau-Pulau Kecil, 3(2), 211-216.

Ghyles, C.L. (2007). Singa toxin-producing Escherichia coli: an overview. J. Anim. Sci., E45-E62.

Hai, H. N. T., Rimbawanto, A., Prastyono., K, N. K. \& Wu, H. (2019). Genetic improvement for essential oil yield and quality in Melaleuca cajuputi. J. Industrial Crop and Product, 137, 681-686.

Helfiansah, R., Sastrohamidjojo, H., \& Riyanto. (2013). isolasi, identifikasi dan pemurnian senyawa 1,8 sineol minyak kayu putih (Melaleuca leucadendron L.). Journal of Systems Engineering, 1(1), 19-24.

Li, L., Li, Z. W., Wei, Q., Jia, R. Y., Zhou, L. J., Xu, J., Song, X., Zhou, Y., Du, Y. H., Peng, L. C., Kang, S., \& Yu, W. (2009). antibacterial activity of leaf essential oil and its constituents Cinnamomum longepaniculatum. Internatioal Journal of Clinical and Experimental Medicine, 7(7), 17211727.

Kee, J. L., \& Hayes, E. R. (1993). Farmokologi: Pendekatan Proses Keperawatan. Jakarta: Buku Kedokteran EGC.

Mayasari, D., Jayuska, A., \& Wibowo, M.A. (2013). Pengaruh variasi waktu dan ukuran sampel terhadap komponen minyak atsiri dari daun jeruk purut (Citrus hystrix DC.). Jurnal Kimia Khatulistiwa, 2(2), 74-77. 
Maulidah, S. (2010). Struktur pasar minyak kayu putih (Melaleuca leucadendron oil). Jurnal Manajemen Pemasaran, 5(1), 9-13.

Mat, S. C. \& Idroas, M.Y. (2019) optimisation of viscosity and density of refined palm oilMelaleuca cajuputi oil binary blends using mixture design method. Renewable Energy, 133, 393-400

Nasronudin (2011). Penyakit Infeksi di Indonesia Solusi Kini dan Mendatang. Surabaya: Airlangga University Press.

Nazeh, M. A., Nor, Z. M., Mansor, M., Azhar, F., Hasan, M. S., \& Kassim, M. (2015). antioxidant; antibacterial activity and phytochemical characterization of Melaleuca cajuputi extract. Complementary and Alternative Medicine, 15(385), 1-13.

Oyedemi, S. O., Okoh, A. I., Mabinya, L. V., Pirochenva, G., \& Afolayan, A. J. (2009). The proposed mechanism of bactericidalaction of eugenol, alpha terpineol, and gama terpinene againts Listeria monocytogenes, Streptococcus phyogenes, Proteus vulgaris, and Escherichia coli. Journal of Biotechnology, 8(7), 1280-1826.

Padalia, R. C., Verma, R.S., Chauhan, A., Goswami, P., Verma, S.K., \& Darokar, M.P. (2015). Chemical composition of Melaleuca linarrifolia $\mathrm{Sm}$. from India: a potential source of 1,8-cineole. Industrial Crops and Products, 63, 264-268.

Painuli, S., Rai, N., \& Kumar, N. (2016). Gas Chromatography and mass spectrometry analysis of methanolic extract of leaves of Rhododendron Arboretum. Asian J. Pharm. Clin. Res., 9(1), 101104.
Pankey, G.A., \& Sabath, L.D. (2004). clinical relevanse of bacteriostatic versus bactericidal mechanisms of action in the treatment of Gram-positive bacterial infection. Clinical Infectious Diseases, Vol 38(6), 864-870.

Pelczar, M.J., \& Chan, E.C.S. (1988). Dasar-dasar Mikrobiologi. Jakarta: Universitas Indonesia Press.

Rahmi, Y., Darmawi., Abrar, M., Jamin, F., \& Fahrimal, Y. (2015). Identifikasi bakteri Staphylococcus aureus pada preputium dan vagina kuda. Jurnal Medika Veterinaria, 9(2), 154-158.

Rusli, M.S. (2010). Sukses Memproduksi Minyak Atsiri. Jakarta: Agromedia Pustaka.

Sawu, M.S.M., Nitbani, F.O., \& Lerrick, R.S. (2018). Analisis minyak kayu putih (Melaleuca cajuputi Powell) asal Pulau Flores. Chem. Notes, 1(1), 1523.

Susanto, M., Doran, J., Arnold, R., \& Rimbawanto, A. (2003). Genetic variation in growth and oil characteristics of Malaleuca cajuputi subsp. cajuputi and potential for genetic improvement. Journal of Tropical Forest Science, 15(3), 469482.

Sutrisno \& Retnosari, R. (2018). Profile of the indonesian essential oil from Melaleuca cajuputi. Advances in Engineering Research, 171, 14-19.

Warsa, U.C. (1994). Mikrobiologi Kedokteran. Jakarta: Bina Aksara.

Wijayati, N., Astutiningsih, C., \& Mulyati, S. (2014). Tranformasi $\alpha$-pinena dengan bakteri Pseudomonas aeruginosa AATC 25923. Biosaintifika, 6(1), 24-28. 